\title{
触 New Disease Reports \\ First report of Dickeya dadantii causing a new disease of apple trees in Brazil
}

\author{
C. Ogoshi ${ }^{1 *}$, F.P. Monteiro ${ }^{1}$, W.F. Becker ${ }^{1}$, M.V. Kvitschal ${ }^{1}$, Y.F. Cardoza ${ }^{2}$, J.G. Zanin ${ }^{2}$ and V. Duarte ${ }^{2}$ \\ ${ }^{1}$ Agricultural Research and Rural Extension Company of Santa Catarina State (EPAGRI), Experimental Station of Caçador, \\ Rua Abílio Franco, 1500, Caçador, Santa Catarina, Brazil; ${ }^{2}$ Agronômica - Phytosanitary Diagnosis Laboratory and \\ Consulting, Av. Ipiranga, 7464, Conjunto 1202, Porto Alegre, Rio Grande do Sul, Brazil
}

*E-mail: claudioogoshi@epagri.sc.gov.br

Received: 29 Nov 2018. Published: 04 Mar 2019. Keywords: Erwinia, Malus pumila, Santa Catarina

In March 2017, canker symptoms were observed in the branches and stems of several apple trees (Malus pumila) in an orchard located at the EPAGRI Experiment Station of Caçador in Santa Catarina State, Brazil (Fig. 1). Intense bacterial exudation from wounds caused by pruning, and colonisation and discoloration of the pith and conducting vessels, especially the xylem, was observed (Fig. 2). The leaves of affected trees wilted and ultimately trees died (Fig. 3). This report raised concerns because of the government's contingency plan to respond to the introduction of fire blight caused by Erwinia amylovora (Ministério da Agricultura, Pecuária e Abastecimento, 2016).

A bacterium was isolated from affected plants. The isolated bacterium induced a hypersensitivity reaction in Nicotiana tabacum and Kalanchoe blossfeldiana 24 hours after inoculation. Isolated colonies were Gram and oxidase negative, catalase positive, facultatively anaerobic and formed white to cream colonies on nutrient dextrose agar. No fluorescent pigmen was observed on King's B medium. The isolate fermented glucose, reduced nitrates to nitrites, grew at $39^{\circ} \mathrm{C}$ and macerated potato and carrot slices. The bacterial culture was stored in the IBSBF Culture Collection (WDCM $110)$ under the code IBSBF 3288 . The biochemical and physiological tests indicated that the isolates belonged to Enterobacteriaceae. Lateral flow immunoassays (Ea Agristrip; Bioreba, Switzerland) and molecular detection with real-time PCR using the specific primers and probe hpEaF/ hpEaR and $\mathrm{hpEaP}$ (Gottsberger, 2010) for detection of E. amylovora were negative.

Metabolic profiling (Biolog GEN III) of one sample of the bacterial suspension which was cultured on Biolog universal growth medium, indicated that the isolate had a high similarity to Pectobacterium carotovorum subsp. brasiliensis. However, PCR on DNA isolated from the bacterial suspension using primers $\mathrm{Y} 1 / \mathrm{Y} 2$ (Darrasse et al., 1994) specific for Pectobacterium, was negative, whereas PCR with primers ADE1/ADE2 (Nassar et al., 1996) specific for Dickeya, was positive. DNA sequencing of the PCR product (420 bp) for Dickeya spp. generated sequence of $329 \mathrm{bp}$ (GenBank Accession No. MK391539) which had 99\% identity with Dickeya dadantii (CP002038), covering 93\% of the sequence. A PCR designed to amplify the V3-V4 region of the $16 \mathrm{~S}$ rDNA resulted in a product of $1417 \mathrm{bp}$ (MH045065). The PCR reaction conditions were at $95^{\circ} \mathrm{C}$ for $5 \mathrm{~min}$, followed by 40 cycles of $95^{\circ} \mathrm{C}$ for $15 \mathrm{~s}, 63^{\circ} \mathrm{C}$ for $30 \mathrm{~s}$, $72^{\circ} \mathrm{C}$ for $90 \mathrm{~s}$, and $72^{\circ} \mathrm{C}$ for $5 \mathrm{~min}$. Comparison of our sequence with sequences in Genbank showed $99 \%$ identity with $D$. dadantii (LC029911) and synonymous Erwinia chrysanthemi (GU252371). Our isolate clustered with $D$. dadantii and $E$. chrysanthemi in a phylogenetic tree (Fig. 4). Realtime PCR with primers dadantiiF/dadantiiR and probe dadantiiP (van der Wolf et al., 2014), specific for $D$. dadantii, was positive, confirming the result of the 16S DNA region sequencing.
Terminal branches of apple cvs. Royal Gala and Fuji Suprema cultivars were dipped in $100 \mathrm{ml}$ of either sterilised distilled water (control) or a bacterial cell suspension $\left(10^{9} \mathrm{CFU} \mathrm{ml} / \mathrm{l}\right)$. Five days after inoculation, terminal branches of both cultivars showed leaf necrosis followed by wilt and death. In addition, the vascular system of inoculated branches darkened (Fig. 5). No symptoms were observed in control plants (Fig. 5). The pathogen was re-isolated from symptomatic branches, fulfilling Koch's postulates. To our knowledge, this is the first report of $D$. dadantii causing disease in an apple tree in the world. Our proposal is that the disease should be called "Dickeya canker".

\section{Acknowledgements}

We are thankful to EPAGRI and to Valdecir Perazzoli, Daniela Alves Cardoso, Jonas Borba Pereira and Juliane Fernandes.

\section{References}

Darrasse A, Priou S, Kotoujansky A, Bertheau Y, 1994. PCR and restriction fragment length polymorphism of a pel gene as a tool to identify Erwinia carotovora in relation to potato diseases. Applied and Environmental Microbiology, 1437-1443.

Gottsberger RA, 2010. Development and evaluation of a real-time PCR assay targeting chromosomal DNA of Erwinia amylovora. Letters in Applied Microbiology 51, 285-292.

http://dx.doi.org/10.1111/j.1472-765X.2010.02892.x

Ministério da Agricultura, Pecuária e Abastecimento, 2016. Instrução Normativa No. 34, de 25 de agosto de 2016. http://www.agricultura.gov.br/ assuntos/sanidade-animal-e-vegetal/sanidade-vegetal/arquivos-dpcp/INMA PAn3425.08.2016_PlanodecontingnciafogobacterianoErwiniaamylovora.pd f (Accessed 19 December 2018)

Nassar A, A D, Lemattre M, Lemattre M, Kotoujansky A, Dervin C, Vedel R, Bertheau Y, 1996. Characterization of Erwinia chrysanthemi by pectinolytic isozyme polymorphism and restriction fragment length polymorphism analysis of PCR-amplified fragments of pel genes. Applied and Environmental Microbiology 62, 2228-2235.

van der Wolf JM, de Haas BH, van Hoof R, de Haan EG, van den Bovenkamp GW, 2014. Development and evaluation of Taqman assays for the differentiation of Dickeya (sub)species. European Journal of Plant Pathology 138, 695-709. http://dx.doi.org/10.1007/s10658-013-0343-Z van der Wolf JM, de Haas BH, van Hoof R, de Haan EG, van den Bovenkamp GW, 2014. Development and evaluation of Taqman assays for the differentiation of Dickeya (sub)species. European Journal of Plant Pathology 138, 695-709. http://dx.doi.org/10.1007/s10658-013-0343-z

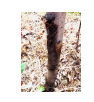

Figure 1

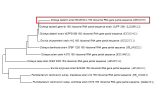

Figure 2
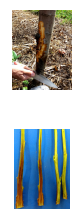

Figure 3

To cite this report: Ogoshi C, Monteiro FP, Becker WF, Kvitschal MV, Cardoza YF, Zanin JG, Duarte V, 2019. First report of Dickeya dadantii causing a new disease of apple trees in Brazil. New Disease Reports 39, 8. http://dx.doi.org/10.5197/j.2044-0588.2019.039.008 (c) 2019 The Authors

This report was published on-line at www.ndrs.org.uk where high quality versions of the figures can be found. 